\title{
Power, Composition, and Decision Making: The Behavioral Consequences of Institutional Reform on Brazil's Supremo Tribunal Federal
}

\author{
Scott W. Desposato \\ University of Zurich; University of California, San Diego \\ Matthew C. Ingram \\ University at Albany, State University of New York \\ Osmar P. Lannes, Jr. \\ Câmara dos Deputados, Brasília; School of Law, University of California, \\ Berkeley
}

How does a court's policy-making authority shape the nature of judicial behavior? We argue that judicial systems that limit policy-making authority also discourage the politicization of courts, encouraging judges to think narrowly about the interests of litigating parties. In contrast, granting a court high policy-making authority - affecting potentially thousands of cases and other branches of government-naturally encourages judges to consider broader ideological principles. Typically, unraveling cause and effect would be difficult, as judicial behavior and institutions are usually stable and endogenous. But an especially stark sequence of political and institutional changes in Brazil affords analytic leverage to explore these questions. A series of judicial reforms greatly expanded the Brazilian Supreme Court's authority, and our analysis of judicial decisions shows the emergence of a political cleavage on the court after these reforms. (JEL C140, K39, K49)

\section{Introduction}

The policy-making authority of constitutional courts worldwide has expanded dramatically since the 1980s (e.g., Tate and Vallinder 1997; Ginsburg 2003; Hirschl 2004). Courts with weak policy-making authority - defined here as consisting of (1) the lack of docket control,

Previous drafts were presented at the 2011 meeting of the Law and Society Association, the 2011 meeting of Research Committee 09 (RC09, Comparative Judicial Studies) of the International Political Science Association, and the 2012 meeting of the Latin American and Iberian Law and Economics Association (ALACDE). For their helpful comments, the authors would like to thank conference participants and discussants. We are especially grateful to two anonymous reviewers and the journal's editor, Lee Epstein. All remaining errors are our own.

The Journal of Law, Economics, and Organization, Vol. 31, No. 3 doi:10.1093/jleo/ewu018

Advance Access published November 4, 2014

(C) The Author 2014. Published by Oxford University Press on behalf of Yale University.

All rights reserved. For Permissions, please email: journals.permissions@oup.com 
(2) narrow, inter partes effects, and (3) non-binding effects ${ }^{1}$ - are more likely to find themselves overloaded with repetitive cases. Reforms in these settings that expand policy-making authority aim to solve a set of problems associated with overcrowded dockets, including long delays, inefficiency, limited access due to the aforementioned delays and inefficiency, and low or decreasing public confidence in the judiciary's ability to solve conflicts due to all of the preceding concerns. In short, enhancing the policy-making authority of judges can have many salutary operational benefits for high courts.

Yet, reforms intended to solve one set of problems can have unintended consequences. Increasing the policy-making authority of judges on peak courts - that is, establishing docket control, as well as general (erga omnes), binding effects - generates new incentives for judges to think beyond the particular interests of the parties to the case, even to craft broad solutions to recurring or trenchant conflicts. These new incentives can alter the strategy of judicial decision making and judicial selection, intensifying the salience of policy programs with ideological orientations, and setting in motion new inter-branch relations. Indeed, if the increase in policy-making authority is paired with changes in the partisan composition of constitutional courts, an institutional reform designed to simply reduce the size of crowded dockets has the potential to trigger dramatic changes in the partisan nature of judicial politics.

In this paper we explore the impact of policy-making authority on judicial behavior. We focus on the case of Brazil, a civil law system in which judging has historically been regarded as legalistic and largely apolitical, and where judges have historically had low policy-making authority.

The high court's power in this regard was greatly expanded in a series of reforms in the early 2000s. We test for an impact of these reforms by collecting and examining an original data set of all decisions on a major class of constitutional review cases (Direct Constitutional Actions, or ADIs) considered by the Brazilian Supremo Tribunal Federal (STF) from 1989-2010. Using both spatial and nonparametric methods, we find evidence of an emerging partisan cleavage. We argue that this evolution is a function of both (a) an ideological re-alignment on the court after the 2002 general election, and (b) reforms granting increasing formal judicial authority which were intended to focus the court's attention on larger constitutional questions. Crucially, changes in court composition alone do not trigger the partisan cleavage. Rather, the cleavage appears

1. A more complete conceptual definition of policy-making authority might include jurisdiction. We conceptualize policy-making authority without reference to jurisdiction primarily because the 2004 reforms did not alter the court's jurisdictional boundaries. One could argue that the new requirements for a showing of "general repercussions" in RE cases reduced the ability of this type of case to reach the court, affecting the court's jurisdiction, but we address this as docket control. In short, we do not discuss variation in jurisdiction in the remainder of the paper because there is none to discuss, and any discussion of jurisdiction would be redundant with our discussion of docket control. 
only after a substantial increase in the policy-making authority of the court. Thus, the institutional reform was a necessary condition for the behavioral change to take place. Our findings shed light on the institutional sources of behavioral transformations on peak courts within civil law systems and the unintended consequences of institutional reform, contributing to a growing literature on comparative judicial politics.

We proceed in four steps. We first outline a theory about how the institutional expansion of judges' policy-making authority can alter the decision-making calculus of judges, and identify the empirical implications that flow from such an argument. We then introduce the Brazilian constitutional court, which has been widely characterized as apolitical and pragmatically professional. We describe the institutional changes affecting the policy-making authority of judges on this court and changes in the partisan composition of the court. In this section, we also discuss the particular type of constitutional cases we examine. Third, we present our quantitative and qualitative evidence, which reveals an emerging cleavage on the court, and we discuss the key factors driving that change. Finally, we discuss the broader implications for studies of comparative judicial politics, highlighting the main lesson from Brazil, namely, that shifts in the composition of the court paired with institutional reforms that raise the political significance of decision making can activate political cleavages in judicial behavior where they were previously latent.

\section{Institutional Reforms and the Activation of Partisan Cleavages}

Why should institutional reforms that enhance the policy-making authority of judges activate previously latent partisan or ideological cleavages? A closer examination of the contrasting sets of incentives faced by judges on peak courts under conditions of (a) weak policy-making authority and (b) strong policy-making authority clarifies the argument. Reforms that move high courts from (a) to (b) facilitate the expression of otherwise latent partisan cleavages.

First, when policy-making authority is weak, courts have little or no docket control and judges' rulings have narrow, inter partes effects and are nonbinding. The absence of docket control means that judges must hear a wide range of cases, many of which can be repetitive or, if unique, quite trivial, taking up valuable time and resources. Further, after adjudicating these repetitive or trivial cases, the final decision applies only to the parties involved, sometimes as few as two parties, and may only have narrow authoritative or persuasive weight for similarly situated actors in the future. This weak authority has direct and indirect behavioral consequences for high-court judges. Directly, judges have little incentive to look beyond the specific interests of the particular parties to a case in order to examine the broader pattern of social conditions or interactions relevant to the conflict. There is little motivation to invest time, energy, or reputation to stake out a stark, programmatic position on an issue that 
has narrow impact. All else being equal, we should expect judges to think in more narrow, short-term ways, and we should have little expectation that judges will develop a consistent, ideologically-informed, long-term, programmatic jurisprudence when decisions have a particularistic impact. Put briefly, there is little incentive to develop a jurisprudence for as few as two parties.

Indirectly, the weakness of judges' policy-making authority reduces the likelihood of filing the kinds of cases that might call for a broader programmatic jurisprudence, thereby also acting as a brake on the development of ideological profiles for judges. This is because plaintiffs face strong incentives not to litigate issues that affect a large group or class of people since the outcome of any one individual case does not have general effects across similarly situated individuals. For instance, if there is a large social class of people who have been discriminated against, e.g., by race or sex, there is less incentive, ceteris paribus, to develop litigation addressing patterns of social exclusion, inequities, or differential treatment if each plaintiff will have to litigate their own case individually. Thus, judges face direct disincentives to develop a jurisprudence based on program, and indirectly there is less likelihood that judges will see the kinds of cases that call out for solutions based on program. To be sure, some extraordinary cases may surprise by not fitting these expectations, but the incentives should structure this general pattern. Directly and indirectly, weak policy-making authority decreases the likelihood of seeing partisan or ideological cleavages on the court.

In contrast, strong policy-making authority means judges exert docket control and their decisions apply to all (general, or erga omnes effects) and are binding. Docket control allows the court to prioritize matters, channeling time and resources to the more significant conflicts. Returning to the direct/indirect distinction, general and binding effects directly encourage judges on peak courts to consider the interests of the parties to a case, but to also look beyond those particular interests and survey the broader social implications of the decision. Quite unlike the incentives for particularistic decisions that are tailored to the parties under conditions of weak policy-making authority, a strong version of this authority encourages judges to think programmatically about solutions to the conflicts brought before them. Moreover, judges recognize that a decision made in one type of case today can be harnessed or leveraged in another type of case the next day, and can begin to think much more strategically and with longer time horizons about the interests included or excluded in their developing jurisprudence. Indirectly, plaintiffs are also more likely to initiate the kinds of cases that raise collective- or group-based issues, so judges are more likely to be called upon to think broadly about these issues.

A few important caveats and clarifications are required here. First, we are not arguing that institutional change directly makes judges more ideological-just that reforms that enhance policy-making authority can affect the role that ideology plays in decision-making. Existing theories of 
judicial decision-making posit that judges are motivated by partisanship or ideology (e.g., Segal and Spaeth 2002; Sunstein et al. 2004, 2006), and behave strategically vis-à-vis each other and external actors in the pursuit of their policy preferences (e.g., Epstein and Knight 1998; Helmke 2005; Staton 2010). Indeed, by expecting enhanced policy-making authority to provide the conditions for the expression of partisan cleavages, we anticipate that the ideological motivations are there in the first place. We only argue that judges' ideological beliefs remain latent under conditions of low policy-making authority and become patent under conditions of increased authority. In addition, a key assumption is that there is a diversity of opinions on the court; increasingly ideological behavior will only generate cleavages on a court when judges have ideological disagreements. This diversity on the court is most often a function of appointments.

Stated differently, judicial attitudes are always there, but there is more ideological diversity on a court that has experienced macro-political changes (e.g., electoral turnover in the executive branch) that translate into judicial appointments by a wider range of politicians. However, this is where the attitudinal literature stops, assuming that ideological differences express themselves once on the court. The strategic literature takes up the idea that judicial behavior is interdependent, with individual preferences constrained by the preferences of other actors, the internal rules of the court, and the external strategic environment, including separation of powers and public opinion (e.g., Epstein and Knight 1998). Comparatively, there is increasing attention to how these dynamics play out in authoritarian regimes, new democracies, and across different countries (e.g., Ginsburg 2003; Helmke 2005; Staton 2010; Kapiszewski 2012). Recent work has also focused on the political consequences of different legal traditions (e.g., Powell and Staton 2009; Garoupa et al. 2013; Powell 2013). However, there is little comparative work on the attitudinal model (cf. Amaral Garcia et al. 2009; Garoupa et al. 2013), and even less attention outside the United States to the way judicial behavior changes longitudinally as institutional reforms alter the policy-making authority of courts. We are unaware of comparative research that demonstrates how institutional reforms alter the salience of partisan differences on a nation's peak court. Put more starkly, while the attitudinal model assumes ideological differences are expressed, and the strategic model emphasizes factors that constrain the expression of ideology, we identify institutional changes that-whether intended or unintended-have the effect of encouraging the expression of partisan differences. ${ }^{2}$

Empirically testing our argument is generally difficult because in many systems courts evolve gradually, and there are expectations of endogeneity between judicial behavior and judicial institutions. An ideal context for testing (provided by Brazil) would be one of dramatic and sequential changes in court composition and then in policy-making authority.

2. We are grateful to an anonymous reviewer for highlighting this point. 
In this context, our theory predicts that cleavages on the court will not immediately appear after compositional changes - because the institutions do not motivate broader thinking in judicial decision making. Instead, cleavages will appear or deepen only after an increase in policy-making authority. If the cleavages appear before the increase in authority, that would be more in line with a standard attitudinal argument, and strong evidence against our argument about the behavioral consequences of institutional reform. In sum, especially strong evidence in favor of our argument would consist of the following sequence: a marked shift in the partisan composition of the court accompanied by no partisan cleavage, followed by an increase in authority and then the appearance of a partisan cleavage.

\section{Case Selection: Brazil's STF and ADIs}

We focus herein on the Brazilian STF for several reasons. Brazil is an emerging power, its judiciary is understudied, and it deserves attention in its own right. More importantly, Brazil's high court is a crucial case for the study of the behavioral consequences of institutional reforms on peak courts. Brazil's STF has previously been regarded as epitomizing much of what is traditionally understood about judging on high courts in civil law systems: empirical studies consistently find that judges are persistently formalist, legalist, and apolitical. A common finding is that the recruitment and selection process prevents an overly partisan court (Nunes 2010), and the ethos of professionalism trumps ideology (Brinks 2005; Taylor 2008; Kapiszewski 2010; 2011b). Put otherwise, behavior on the STF has largely been understood as illustrative of the paradigm of judging in civil law systems.

However, over the past 15 years, a series of institutional reforms have progressively increased the policy-making authority of the court, beginning mainly in 1999, but most emphatically in 2004. Alongside these institutional reforms, the presidency has been occupied by politicians representing a steady progression from right to left along the ideological spectrum, beginning with the former supporter of the military regime, José Sarney (1985-89), through two administrations of the centrist Fernando Henrique Cardoso (1995-2002), to the two administrations of the centerleft Luiz Inácio Lula da Silva (2003-10). Each administration appointed judges to the court, so the partisan composition of the court varies over time in ways that enhance analytic leverage. Thus, on both our key variables of interest, there is rich variation in Brazil.

Moreover, the progressive expansion of judges' policy-making authority on this peak court has been preceded by changes in the partisan composition of the court. This combination of political-then-institutional change is ideal for testing the behavioral consequences of institutional reform, as outlined in the empirical implications of our argument above. If a partisan cleavage emerges after a change in court composition but 
before the expansion of authority, the phenomenon is more likely attitudinal. If, however, there is a change in court composition but the partisan cleavage only appears after a subsequent expansion of authority, then our institutional argument is supported. In sum, the combination of variation in institutional reform and court composition, as well as the sequence of political and institutional changes, generate a kind of natural experiment for our research question. In the context of changing partisan composition of the High Court, reforms occur that are intended to bring about administrative improvements. We are interested in whether the expansion of judicial authority had the unintended consequence of activating partisan cleavages on the court.

In this paper, we test the impact of partisan and institutional changes on judicial behavior in Brazil with an original dataset of every case of Direct Constitutional Action (Ação Direta de Inconstitucionalidade, ADI) decided by the STF from the new, 1988 Constitution until the end of the second Lula administration in 2010. We test for emerging political cleavages on the court as evidence of an emerging attitudinal or ideological division among justices. ADIs constitute the central mechanism of abstract constitutional review in Brazil, and they capture some of the most high-profile constitutional clashes (see Data and Results). ${ }^{3}$

Some observers might argue that ADIs are the wrong type of decision for this analysis for alternate reasons: (a) ADIs constitute a small portion of the STF's workload, (b) ADIs are the cases where partisan cleavages are most likely to appear, or (c) ADIs can be viewed as being less about subjective individual rights and more about objective constitutionality. First, ADIs do indeed constitute a small portion of the STF's work, but they are also some of the most important cases that come before the court. Kapiszewski (2011a) identifies the 55 most politically important cases that reached the STF between 1985 and 2004, and the majority of those cases were ADIs (30, or 55\%). Second, because of their importance, ADIs may draw out partisan cleavages, but there is little evidence that suggests, ex ante, that partisan differences should be most likely to manifest themselves in ADI litigation. Indeed, given that ADIs are a mechanism of abstract review, some scholars may argue that partisan cleavages are less likely here than in cases of concrete review, since more immediate

3. The sample includes all ADIs, as noted, and excludes all other types of cases, including ADOs (Ação Direta de Inconstitucionalidade por Omissão) and ADPFs (Arguição de Descumprimento de Preceito Fundamental). In doing so, we follow other authors who have focused on a single class of cases (e.g., Taylor 2008), and also reason that doing so allows us to control for procedural differences across types of cases. Further, the volume of ADIs far exceeds the volume of ADOs or ADPFs. For instance, in 1995 there were more than 100 decisions rendered in ADI cases but none in either ADO or ADPF cases; in 2005 there were more than 250 decisions rendered regarding ADIs, none for ADOs and only 20 for ADPFs; and in 2010, there were again more than 250 ADI decisions, only 3 for ADOs, and 23 for ADPFs (http://www.stf.jus.br/portal/cms/verTexto.asp?servico=estatistica; accessed January 6, 2014). 
interests are at stake in, as Article III of the US Constitution states, actual cases or controversies. Lastly, as raised by the third potential critique related to a focus on ADIs, but which is also related to the likelihood of observing partisan cleavages in ADIs, this type of case may be an unlikely place to observe partisan cleavages because ADIs are viewed by some as being less about subjective rights and more about objective constitutionality. That is, ADI litigation is less about righting a wrong suffered by an individual or group of citizens and more about establishing the centrality or supremacy of the constitution. Evidence of this is in passage (a) and (b) of Law 9.868, which does not allow plaintiffs to desist from an ADI once initiated. That is, once the constitutional question is raised, it must be answered, even if the original plaintiff desists. ${ }^{4}$

However, it is also undeniable that, like much constitutional litigation that raises formal, procedural, and technical-legal issues, there are real rights at stake. Even if rights-related litigation via ADIs is a relatively recent phenomenon (Brinks 2011: 142; Kapiszewski 2011a: 160), the use of this mechanism for rights-related cases undercuts the argument that these cases are only used to maintain objective constitutional order. A few examples demonstrate the kinds of very high-profile rights that hinge on the outcome of these cases: (1) ADI 3.197 and 3.333, which dealt with racial quotas and affirmative action in Brazilian universities, (2) ADI 3.239 , raising the constitutionality of land invasions by Afro-Brazilian descendants of the settlers and inhabitants of quilombos, independent communities of freed or escaped slaves during the colonial period, (3) ADI 3.510, which pitted the ability to conduct scientific research on stem cells against an argument combining elements of right-to-life and human dignity, (4) ADI 4.077, which tackled freedom of information and the transparency of government records, and (5) ADI 4.277, decided in 2012, in which the STF extended the concept of family to same-sex couples.

Still, the presumably "objective" character of ADIs merits further emphasis, along with the concentrated and abstract nature of ADI review, as attention to these features of review helps understand why the expansion of policy-making authority may be especially felt by ADIs, particularly after 2004. We turn now to a discussion of these features of constitutional review in Brazil, the expansion of policy-making authority, and changes in court composition.

\section{The Brazilian Court and Implications of Recent Changes}

In this section we provide an overview of the Brazilian judicial system and the literature on decision making on the Brazilian high court,

4. Though the STF need not reach a final decision on the merits for a variety of procedural reasons. For instance, if the challenged law or other state action is revoked, replaced, or otherwise nullified, the issue is moot and the legal action loses its object (perda de objeto), e.g., ADI 3.197. 
the Supremo Tribunal Federal. We then discuss a series of powerful reforms that enhanced judicial authority, as well as political factors that diversified the court's partisan composition. We apply our theoretical framework and conclude this section with a series of hypotheses. We first discuss the court prior to major reforms, focusing on the limited policy-making authority of judges, then show how major reforms, especially in 2004, greatly increased the court's influence. Put simply, we can speak of a dramatic expansion in the STF's powers as of 2004.

A brief overview of the Brazilian judiciary clarifies the significance of the 2004 reform. The Brazilian judicial system is organized into distinct hierarchies of courts that deal with specific types of legal issues. There are subnational judicial institutions within each of the 27 states, but at the federal level the judiciary is generally understood as structured into four legal arenas: civil and criminal courts, military, labor, and electoral courts. Within the first set of institutions, the Supremo Tribunal Federal, or STF, is the apex constitutional court, adjudicating all major national constitutional disputes about the proper separation of powers - horizontal (between branches of government) and vertical (between lower and higher units of the federation), as well as serving as the court of final appeal for all other cases. The STF is relatively accessible, comparable to the constitutional courts of Colombia and Costa Rica as one of the most accessible constitutional fora in Latin America (Taylor 2008: 78). The STF receives thousands of cases every year, and has adjudicated diverse cases (Taylor:3), ranging from economic stabilization programs, privatization policies, affirmative action, and the amnesty law of 1979 that barred prosecution of those guilty of torture and other abuses during the military regime.

Despite the court's accessibility and broad range of cases it has heard, judging on this court - the actual-decision making process of the 11 justices - has been widely regarded as typical of civil law systems. Specifically, while the STF was designed to be a strong court, it exhibited some of the features of civil law judiciaries that limited the legal effects of judicial decisions, rendering the court a weak policy-making institution. Thus, in assessing the overall policy-making authority of the court along Ginsburg's (2003) five axes - accessibility, accountability, tenure, size, and effects - the court would have received high marks on the first four axes, but low marks on the last axis covering the effects of decisions. More to the point, the STFs decisions could not be binding on all public authorities, and the court did not systematically consider the general effects of its decisions. As we will explain below, a key reform in 2004 changed both of these limitations on the effects of the STFs decisions, greatly augmenting its policy-making authority.

This expansion of policy-making authority came with the passage of a national judicial reform in 2004, Constitutional Amendment 45 (EC45), 
which took effect on January 1, 2005. ${ }^{5}$ This reform made several changes in the judiciary, but two of the most important were (1) granting the STF the legal concept of precedent, captured in the "súmula vinculante" (SV, literally "binding thesis" or "binding summary") mechanism, and (2) requiring that actions for Extraordinary Review (recurso extraordinário, RE) make a showing of "general effects" or "general repercussions" (repercussão geral). The reform took effect on January 1, 2005, and subsequently a pair of laws in December 2006 (Law 11.417/06 and Law 11.418/06) further regulated SVs and REs. A closer look at each of these components of the 2004 reform demonstrates why we consider this reform to be a significant expansion of authority.

Regarding SVs, this is an action that can be initiated by any of the actors with standing to initiate an ADI. To do so successfully, the petitioning party must show that there are multiple constitutional cases on the issue, and that there is disagreement among the courts or the executive about how to interpret the constitution. Lastly, in order to become an SV, a two-thirds majority of the STF is required (Const. art 103-A; EC45). If successfully issued, the SV ruling supercedes all the consolidated rulings related to the issue, and has general and binding effects on all courts and

5. Some observers familiar with Brazilian constitutional law might wonder why we do not examine a 1999 law that reformed the ADI procedure. While access to the ADI mechanism was broadened by expanding standing in the 1988 Constitution, it was not until Law 9.868/99, which became effective on November 10, 1999, that the process of initiating, processing, and deciding ADIs was fully regulated. Among other things, Law 9.868 addressed the legal effect of ADI decisions, establishing that this effect would apply to all (erga omnes effects), and would also be binding ("vinculante") on the judiciary and all public administration, i.e., the executive. Law 9.868 also regulated Declaratory Actions of Constitutionality (ADCs), which were created by a 1993 law. However, the STF hears very few ADCs and in any case it was not until the 1999 law that the effect of ADCs and ADIs was made clear, so we focus on 1999 as the first clear, post-1988 expansion of policy-making authority (cf. Nunes 2010). Notably, the binding effect of ADIs did not extend to the legislature, and is also generally not regarded as extending to the STF itself, since it can change jurisprudence over time (Camargo 2006). Given this institutional expansion of policy-making authority, especially given its focus on ADIs, some readers may argue we should anticipate that partisan cleavages would be discernible from 2000 forward compared with the prior period from 1989-99. We acknowledge that the 1999 law at least nominally enhanced the policy-making authority of the STF, but that we should not expect a partisan cleavage for several reasons. First, President Cardoso only appointed three judges to the STF, and all of these came late in his administration, mostly in the second half of his second term (compared with eight by Lula, with four in the first half of his first term!). Thus, the composition of the court did not change much in order to generate the basic political diversity that would underpin a partisan cleavage. Second, the increase in policy-making authority from the 1999 law was negligible compared with the factors increasing this authority in 2004. For an ADI ruling to be binding in a later case, the facts and legal question raised in the latter case had to be virtually identical (Rcl 9662, stating that legal question must be "similar on all points, if not identical"; authors' translation). This is not the case with the 2004 reform, which encourages STF judges to think very broadly and systematically about their jurisprudential positions and how these positions might be consolidated across a wide range of cases (see discussion below). In any case, we ran a set of auxiliary spatial and nonparametric auxiliary analyses to test for the emergence of a partisan cleavage after 1999 (but before 2002), and did not find one. 
public administration at all levels of government. While the formal effect of an SV ruling is essentially the same as that established for ADIs in 1999, the way an SV can take shape is very different. First, while there have been several thousand ADIs since 1989, there are over a million cases decided by the STF, and many thousands more at the various other levels of the judiciary. In theory, at least, a petitioning party in an SV is able to scan all of these cases for an issue that has been raised repeatedly and for which there appears to be no constitutional consensus. The purpose of the SV, then, is to generate a more homogeneous or uniform jurisprudence for the entire country, across all types of constitutional litigation. The reform will certainly have the effect of reducing caseloads, but we anticipate that this also generated a major incentive for STF judges to think more programmatically about their jurisprudential positions across all cases, including ADIs, as judges may now be forced to reconcile decisions across multiple cases in future litigation. Indeed, the second SV that reached the STF (SV2, issued August 10, 2007) relied on six previous ADI decisions as "precedents" that the SV sought to consolidate into a summary jurisprudential statement.

At the same time, in order to be heard by the STF after January 1, 2005, all RE cases - which constitute the single largest class of cases at the STF and number in the hundreds of thousands (!) - must demonstrate that the issue they raise has "general repercussions" (Const. art 102, sec. 3; EC45). At a minimum, this part of the reform endows the STF with at least some degree of docket control. Beyond that, however, the criteria for "general repercussions" require that claimants frame their case of subjective constitutional review in the language of objective constitutional review, again incentivizing STF judges to think beyond the interests of the specific parties to the case. In 2006, Law 11.418/06, reforming the Code of Civil Procedure, went further by specifying more precise criteria for finding "general repercussions". Specifically, general repercussions exist (and the case can therefore be heard), if the case raises issues of economic, social, political, or juridical relevance that "go beyond the subjective interests of the action"6 (Law 11.418/06, art. 2; CPC art. 543-A(1)). More importantly, general repercussions are presumed to exist if the RE is challenging a lower decision that cuts against a súmula or jurisprudência of the STF (CPC art. 543-A(3)). As used in Brazil, a "jurisprudência" is a developing line of similarly motivated decisions, while a "súmula" goes one step further, offering a summary of the cases that compose the jurisprudência. Neither is formally binding or has formal general effects, but both have authoritative weight. However, since the court has gone to the added trouble of formally consolidating its jurisprudência into a súmula, the súmula has more weight than jurisprudência. That is, in the hierarchy of authorities (from low to high), we find jurisprudências, súmulas, and súmulas vinculantes. Thus, if an RE can show that the challenged lower

6. Authors' translation (original: “que ultrapassem os interesses subjetivos da causa”). 
decision cuts against even an evolving line of cases on the STF, general repercussions are presumed. This presumption implicitly affords even evolving lines of jurisprudence greater objective constitutional weight, encouraging judges to think more systematically about the way they decide every one of their cases. Combined with the incentives to consider how individual decisions might be consolidated into an SV, these new rules regarding REs constitute a meaningful increase in the policymaking authority of the court.

In addition to the institutional change in 2004, a parallel political transformation affected the composition of the STF. The Workers' Party presidential victory in 2002 brought the party to the nation's highest office in 2003. Long regarded as the only large programmatic party in Brazil, the ascent of the PT to the presidency can be expected to lead to a more political appointment strategy, with the appointer-new president Luiz Inácio Lula da Silva (Lula) - seeking to pack the court with friendly partisans. These changes suggest an increasing politicization of the court which may result in a new attitudinal judicial politics for Brazil, especially in combination with the institutional change outlined above. Previously, judges had little obvious identification with any political party - even the party of the president that appointed them. But beginning with the first PT administration of President Lula, appointees have had clearer ties to party (Kapiszewski 2010: 55 note 5). Perhaps the most obvious example is Dias Toffoli, who was attorney for a major national labor union (Central Única dos Trabalhadores, CUT), legal counsel for the PT in the Chamber of Deputies, worked on Lula's political campaigns, and was also Lula's Solicitor General (Advogado Geral da União, AGU) before being nominated to the court in $2009 .^{7}$

To be sure, we are not saying that no STF judge before Lula had any kind of political background. Nelson Jobim was so closely tied to the Cardoso administration after his appointment in 1997, having first been Minister of Justice, that he was called the "leader of the government on the STF", and together with Cardoso's other two justices was considered the "government's bench" (bancada governista; ISTOÉ 2000). At least six pre-Lula justices held formal elected office prior to joining the STF, and five of these justices held at least one elected office at the federal level. ${ }^{8}$ An additional justice, Francisco Rezek, was appointed to the court in 1983, resigned to be Collor's Minister of Foreign Relations (i.e., Secretary of State) in 1990, and was later re-appointed by Collor to the court in 1992. ${ }^{9}$

7. Unless otherwise noted, all data on justices' background is from the STF website, which contains biographies and resumes for all justices.

8. Rafael Mayer (mayor), Oscar Correa (state deputy; federal deputy); Paulo Brossard (state deputy; federal deputy; senator); Celio Borja (state deputy and three terms as federal deputy); Mauricio Correa (senator); Nelson Jobim (federal deputy).

9. Prior to joining the court in 1983, Rezek was a federal prosecutor during 12 years (1972-83) of the military regime, rising to Deputy Attorney General (Subprocurador-geral da Republica) in 1979. 
Multiple justices held appointed office at different levels of government, including Gilmar Mendes (appointed by Cardoso), who like Dias Toffoli just mentioned, was AGU. ${ }^{10}$

However, these other justices have been spread out over several administrations. In contrast, aside from Dias Toffoli, four more of Lula's eight nominations held appointed positions in local or federal government (Carlos Britto, Eros Grau, Ricardo Lewandowski, and Menezes Direito), and only three of the eight had previously been judges (Cezar Peluso, Lewandowski, and Direito). Indeed, at least one journalistic account reports statements by Lula that show he sought to place sympathetic, leftist judges on the bench. In August 2007, the STF was populated with six justices selected by Lula - a majority — and was deciding a major case involving the alleged corruption of many of his party's politicians (in a scandal known as the mensalão). As he witnessed the justices he had selected vote against the PT politicians, he reportedly complained, 'all those leftist judges that I nominated are voting against me." According to another journalistic account, the selection of the more apolitical, "technical," or legalist Menezes Direito the following month was due in part to Lula's frustrated reaction to the way his earlier preference for left-leaning judges had backfired in this one case (Studart 2007).

We believe these two changes - the increasing policy-making authority of the court and the increasingly partisan composition of the court-drive a paradigm shift in judicial decision making in Brazil, from a latent partisan cleavage to a patent one. Notably, if the cleavage appears before any institutional change, the primary dynamic is attitudinal and there is little conditioning effect of the institutional reform. However, if the cleavage appears or deepens after the institutional changes, then we can conclude that a partisan cleavage that remains latent under conditions of weak policy-making authority is activated by reforms that increase that authority. The above discussion yields two core hypotheses:

H1: Compositional Change: Cleavages on the court are driven by changes in the court's composition, with the arrival of President Lula's appointments. More specifically, Judicial behavior on the STF should become more partisan or ideological after June 2003, when PT-appointed judges reach the court.

H2: Policy-making authority affects judicial behavior. Latent partisan divisions are activated once judges' decisions have broad policy-making authority. Judicial behavior on the STF should become more partisan or ideological after

10. Aside from federal elected office, Brossard, Mauricio Correa, and Jobim also held the appointed office of Minister of Justice. Gilmar Mendes was Cardoso's Solicitor General (AGU) prior to joining the Court. 
January 1, 2005, in response to the judicial reform of 2004 expanding policy-making authority.

To be clear, we do not anticipate being able to differentiate between liberal and conservative justices, as the attitudinal literature tends to do in the United States (Segal and Spaeth 2002; Sunstein et al. 2006). Rather, we expect to distinguish nonpartisan patterns of collegial decision making from patterns marked by partisan cleavages. We turn now to our empirical analysis.

\section{Data and Results}

We test our hypotheses by examining constitutional decisions for evidence of changes in judicial behavior in response to institutional reforms and different nomination patterns. Using both a spatial model and a nonparametric method, we compare patterns of judicial decision making before and after the key reforms, and before and after the Lula administration. For each part of the analysis, our critical test is whether justices divide on partisan lines or not. We discuss our data below then present our methods and results.

We collected data on every Direct Action of Unconstitutionality ( $A$ c cão Direta de Inconstitucionalidade, or ADI) over the course of more than two decades between 1989 and 2010. These decisions include both merit and procedural questions. Virtually every ADI begins with a procedural issue when the plaintiff files a request for an injunction (called either liminar or medida cautelar), seeking that the underlying state action be suspended until a final decision on the merits. Further, procedural questions frequently arise about whether the case should proceed to the merits. These procedural questions include issues about standing, mootness, and jurisdiction. Thus, there are generally at least two decisions for each ADI - the injunction and the merits decision - and frequently a third procedural decision. ${ }^{11}$ There were over 10,000 ADI decisions between March 1, 1989, and June 18, 2010. Of these, 1258 had some dissension, that is, are nonunanimous, and are therefore included in our analysis. ${ }^{12}$

11. In some of these constitutional cases there were as many as three separate procedural issues and as many as nine total decisions.

12. All data are from STF website (www.stf.jus.br), last accessed November 17, 2011. Some readers may be skeptical of the focus on nonunanimous decisions or wonder how our findings extend to unanimous cases. Existing literature finds that unanimous cases are more likely in easy cases, or in cases where the court is seeking consensus to ensure external legitimacy or compliance with a ruling (see, e.g., Epstein and Knight 1998; Baum 2006). As noted by Songer and Siripurapu (2009), unanimity is also likely where legal constraints restrict the range of decisions, or where strong norms of collegiality exist. Further, quantitative work is not well-suited to identify either of these factors (Songer and Siripurapu: 88-89), so qualitative work on Brazil's high court would be more suited to identify, as Kapiszewski (2012) does, these norms of consensus and collegiality. Of course, the fact that many cases are easy or constrained by legal rules, or that some consensus and collegiality exists, does not mean that ideological differences disappear. For instance, the rate of unanimity on the US Supreme 
We note that there were many other types of cases, and many other decisions (unanimous and nonunanimous) during the same time period. The Brazilian STF does not control its docket (unlike the US Supreme Court), and must process every case filed, though this has changed somewhat after the 2004 reform required some types of cases to meet additional criteria in order to be accepted at the court (e.g., as noted above, recursos extraordinários, REs, must show that the legal issue has general effects or "repercussão geral" among the population). Since 1988, the volume of cases has been increasing dramatically. In 2010 alone, the court decided 103,869 cases and received 71,670 new cases. Contrast this with the 8159 cases filed at the US Supreme Court, of which the Court accepted only $82 .^{13}$

We limited our analysis to decisions on ADI cases for two reasons. First, practically, we do not have the resources to collect data on all STF decisions (a total of well over one million at the close of 2009). Although summaries of the decisions are available online, accurate coding of judicial decisions requires reading the case summaries and searching for decisions. A simple web-scraping program would inaccurately code justice positions, and lead to inaccurate results, because electronic summaries fail to distinguish between justices that take a minority

Court increased from 2008 (33\%) to $2012(49 \%)$. As of April 11, 75\% of the USSC cases have been decided unanimously, with only a single case (McCutcheon v. FEC) decided by a 5-4 vote (see Bhatia 2013; though most of the divided opinions are likely to come in June, towards the end of the term). Despite the rising unanimity and despite McCutcheon representing a small sample $(n=1)$, most observers would agree that the single 5-4 decision in McCutcheon is fairly representative of the ideological division on the court. Justice Ruth Bader Ginsburg agrees with Justice Clarence Thomas $79 \%$ of the time, but that high level of agreement does not negate differences between the two. Indeed, the same methods we employ are used in the United States to estimate judicial ideal points of the US Supreme Court (Martin and Quinn 2002). Lastly, while in the paper we are making claims about the content of the partisan cleavage on the court after 2004, we are using the same kind of non-unanimous decision data to look at patterns in decision-making over time. Our main finding is that - using this same non-unanimous data to examine the Brazilian STF's longitudinal trajectory since 1988 - the current partisan cleavage is a new phenomenon coming on the heels of the 2004 reform. If we had used different data for different time periods, we would be in a weaker analytic position. But we find this new cleavage using the same kind of data over time, diluting the criticism that our findings are an artifact of the non-unanimous data.

We further note that this is a general feature of most decision-making bodies - there are many more unanimous, uncontroversial decisions than there are divisive decisions. Some large legislatures use voice votes or similar mechanisms to quickly pass large numbers of bills that enjoy widespread support. These are typically administrative decisions or policy/ precedent improvements that everyone agrees on. There may be hundreds of such decisions for each controversial roll call in many voting bodies. In that sense, these decisions are not as important. The real question is, when there are contentious issues before a decision-making body, are there regular patterns of division reflecting enduring differences of opinion and preference? Our results show that there is a new pattern of partisan division on the STF.

13. Supreme Court of the United States (USSC). " 2010 Year-End Report on the Federal Judiciary," Appendix p.9 (December 31, 2010); available at: http://www.supremecourt.gov/ publicinfo/year-end/year-endreports.aspx (last viewed February 12, 2011). 
position, and those that were absent or abstained. In other words, the summaries only report the names of judges that were in the majority, and do not list those absent or in the minority. Distinguishing between "not present," "recused," and "nay" requires a careful reading of the decision. Consequently, any web-scraping analysis would be making the unrealistic assumption that all absences were in fact minority positiontaking.

Second, given that we must limit our analysis to a subset of cases, the ADIs generally include many of the most important cases. To be clear, ADIs are not the only mechanism by which the constitutionality of state actions can be challenged. Kapiszewski (2010; 2011a; 2011b), for instance, analyzes 55 important cases adjudicated by the STF between 1989 and 2004, and 24 of these cases were not ADIs. Further, REs are the most frequent, if lower profile, mechanism of review. ${ }^{14}$ Still, more than half of the important cases identified by Kapiszewski - specifically, 31 caseswere ADIs, showing that this mechanism is a central avenue of constitutional review, arguably the most important. Notably, the 1988 constitution expanded standing but still allows only nine actors to initiate ADIs - the President, the Senate, the Chamber of Deputies (lower house of Congress), the Attorney General (Procurador Geral da República, PGR), the legislature of a State or the Federal District, the governor of a State or of the Federal District, the national bar association (Ordem dos Advogados do Brasil, OAB), political parties with representation in the national Congress, and federal unions or other federal professional associations (e.g., the national judges' association, Associação dos Magistrados Brasileiros, AMB).

Our empirical analysis is focused on testing whether there is any evidence that institutional reform increasing the policy-making authority of judges generates a partisan cleavage. Existing research consistently finds that the STF is distinctly nonideological. However, prior studies have examined smaller time periods and smaller samples of cases, so we are cognizant that our broader analysis may yield new findings. Importantly, any finding of a partisan cleavage would cut against the consensus that the STF justices behave nonideologically, provoking a reassessment of the sources of behavior on the STF. More specifically, such a finding would refocus our attention on the institutional conditions that dampen or enable the expression of partisan preferences.

Empirically, we wish to see whether the Court divides along political lines when making decisions. Ideally, we would have some direct measure of each judge's ideology, but as is the case with most judicial scholarship, no such information exists. But we can categorize judges according to the party of their nominating president, a standard practice for judicial studies (e.g., Sunstein et al. 2006). The long-time period we study includes judges

14. More than 13,000 were filed in 2010 alone (http://www.stf.jus.br; last viewed May 31, 2012). 
nominated by military presidents, as well as five civilian presidents from four parties (PMDB, PRN, PSDB, and PT). ${ }^{15}$

Methodologically, we use two broad approaches with very different assumptions to test for ideological differences. First, following much of the literature on judicial politics, we estimate judicial ideal points on decisions using methods derived from a spatial model, and test for systematic differences across political parties in a low-dimensional space. Second, using a more flexible nonparametric method, we test for cleavages between judges based on their partisanship, combining all dimensions simultaneously.

We begin by exploring patterns in the distribution of ideal points using the spatial model, the current standard for measuring judicial preferences, understanding the policy space, and analyzing judicial coalitions and other secondary quantities of interest. The foundations of the model are that decisions and justices can be represented in a judicial ideology space of one or more dimensions, and that decisions reflect preferences or beliefs of judges about the best policy outcome. The typical approach to model judges' decisions is to begin by assuming that judges have single peaked preferences in a low dimensional space that captures all decisions. Each vote by a justice supports either position A or position B. ${ }^{16}$ In this environment, judges will decide for A when

$$
U_{i}\left(A_{j}\right)>U_{i}\left(B_{j}\right)
$$

and for B when

$$
U_{i}\left(A_{j}\right)<U_{i}\left(B_{j}\right)
$$

where $i$ indexes judges, $j$ indexes decisions, and $U$ is the function that maps legislators' preferences onto each case. Typically, $U$ is a function of the distance from judge $i$ 's ideal point $\theta_{i}$ and the impact of a case decision for position $A$ or position $B$, plus some random error:

$$
\begin{aligned}
& U_{i}\left(A_{j}\right)=f\left(\theta_{i}, A_{j}\right)+\varepsilon_{i j A} \\
& U_{i}\left(B_{j}\right)=f\left(\theta_{i}, B_{j}\right)+\varepsilon_{i j B}
\end{aligned}
$$

The specific form for $\boldsymbol{f}$ is chosen to be a monotonic function of the distance between $\theta_{i}$ and $A_{j}$, with typical choices of $f$ being gaussian or quadratic. Estimation is achieved using maximum-likelihood, nonparametric, or markov-chain monte carlo (MCMC) methods. Because we are analyzing a small decision-making body, we use Poole's (2000) Optimal Classification, a nonparametric estimation technique.

15. Presidents Sarney and Franco were both nominally members of the PMDB, the Party of the Democratic Movement of Brazil. Neither were committed partisans, and neither stayed in the party after their terms ended.

16. In typical roll-call applications, these are presented as a status quo and alternative. 


\section{Results}

Figure 1 shows justice ideal points when combining all case data from the period 1990 to 2010. Appointing presidents are represented by colors, with Lula's justices as red, Cardoso's as dark blue, Collor's as light blue, Franco's as cyan, Sarney's as black, and the military presidents' justices as green.

The obvious trend in the data is the division of the court according to justices' appointing presidents. Lula's justices all occupy the far left of the ideal space. With few exceptions, all other justices are on the other side of the ideal space. The remainder of the justices are on the right half of the graph, and the array of ideal points hints at other presidential differences, but only weakly. Note for example that on the first dimension, the Cardoso appointees have very similar locations, as do most Collor appointees, and most military (green) appointees. The Sarney appointees are perhaps the most diverse-occupying center left and right positions.

The first dimension spread roughly corresponds to what one would expect ideologically, with the Workers' Party at one end, the Cardoso judges in the middle, and the Collor and military presidents further to the other side. The only exception is the Sarney administration, whose judges are spread around the center of the space. This space may indeed correspond roughly to a traditional left-right spectrum, but it could also encompass other dimensions of judicial disagreement. ${ }^{17}$

The outlier on the second dimension is Marco Aurelio. Justice Aurelio is known for erratic independence and for being an "obstructionist" on the court - and perhaps not making decisions according to the spatial model described above (see Appendix A). Anecdotes from judicial staff tell of cases where Aurelio argued eloquently against a bill, but when his arguments succeeded in swaying the court, he changed his position so that he would still be in the minority group! This erratic behavior violates key assumptions of the spatial model, so we exclude this justice from the rest of the spatial analysis. ${ }^{18}$

A scree plot (not shown) suggests low dimensionality to the space, with results consistent with a one-dimensional voting matrix. The first dimension explains about twice as much variance in the roll-call space than any higher dimension, and a test of dimensionality fails to reject the null hypothesis that the space is unidimensional. ${ }^{19}$

17. We read approximately 10 of the cases with near vertical cutting lines (those that define the first dimension space). Our early analysis does not suggest any obvious trend in the space. Fully exploring the nature of this conflict is beyond the scope of this paper but addressed in a separate working paper available from the authors.

18. We also generated a version of Figure 1 excluding Marco Aurelio, but there were no major differences in the distribution of ideal points.

19. We randomly generated multiple unidimensional data matrices of equal size and rank as that of the Brazilian Supreme court, then tested the dimensionality of these. Any deviations from unidimensionality in this case would be due to random error-because we generated the data from a unidimensional model. The typical scree plot from this simulation was similar to 


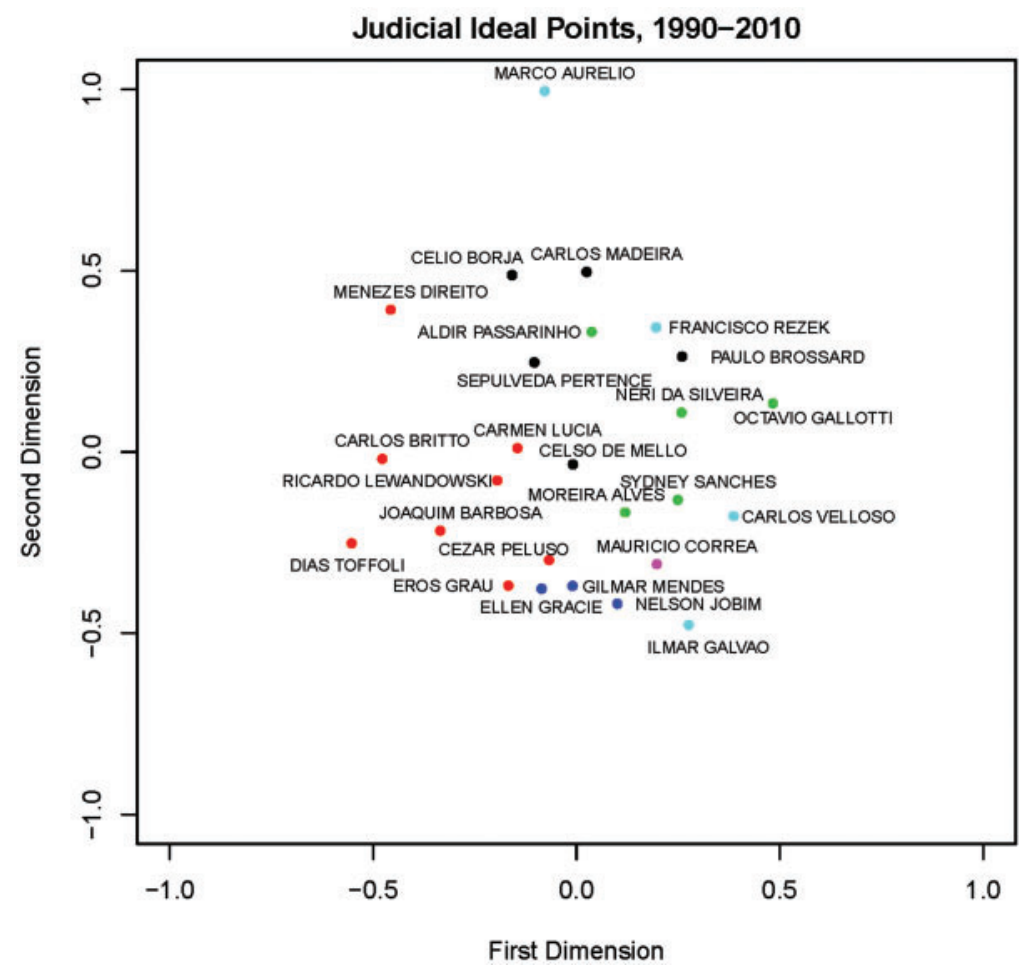

Figure 1. Judicial Ideal Points, 1990-2010.

We supplement the visual analysis with a formal test for the relationship between appointing president and ideal points by comparing the mean ideal point of each president's appointees. More formally, let justices' ideal points be a function of their appointing president's ideal point and a random error:

$$
\theta_{i j}=\bar{\theta}_{j}+\varepsilon_{i j}
$$

where $\theta_{i j}$ is the ideal point of the $i$-th justice appointed by president $j, \bar{\theta}_{j}$ is the mean ideal point for president $j$ 's justices, and $\varepsilon_{i j}$ is the random error. With standard assumptions about the distribution of the $\varepsilon$ 's, this translates into an analysis of variance model, where the null hypothesis is that the presidential means are all equal to the grand mean, and the alternative is that the presidential means vary.

ANOVA of course has at least two problems here. The first is that it is a one-dimensional analysis, though we have estimated two dimensions of ideal points. The second is that there are not enough judges to reach 
standard minimum dataset sizes for this method. In response, we also show results for a MANOVA and for a Kruskal-Wallis nonparametric test, which is rank-based and robust in small datasets.

Table 1 shows results from these tests on several subsets of the data. The first two columns show results when jointly analyzing all judges and decisions over the 20 years of cases we collected. The first has all judges; the second drops the erratic Justice Aurelio. The results in Columns 1 and 2 are almost identical, and tell the same story as Figure 1: the groupings of judges by appointing president are statistically significant for the first dimension ANOVA, Kruskal-Wallis, and for the MANOVA. The second dimension differences are also significant or marginally significant.

Our results are robust, significant, and visually striking - and they disagree with most of the existing literature on the Brazilian STF. Previous work almost unanimously characterizes the court as a highly professional, nonideological court where decisions are always made on the basis of legal arguments or pragmatic, apolitical concerns, such as macroeconomic considerations regarding national stability. Our results show that this is indeed not the case! There is a strong divide on the court that corresponds to the president who made the appointment.

The division is primarily driven by a divide between President Lula's many appointees, and the rest of the court, with weaker evidence of divisions for earlier appointees. Indeed, we also tried running our analysis with just a single covariate - an indicator variable for "appointed by Lula." We tested this model against one including all the presidential indicator variables. The statistical analysis suggests that the cleavage is between Lula appointees and other appointees; we could not reject the null that, once controlling for Lula appointees, none of the other presidential appointments significantly improved the fit $(p$-value $=0.72$; results not shown).

This aggregate analysis suggests a transformation of the STF, with a cleavage that has accompanied the rise of the Workers' Party (PT). But do these changes reflect institutional reforms, or attitudinal diversity associated with President Lula's appointments? To explore our hypotheses, we continue our analysis by analyzing subsets of decisions. We begin by examining two sets of decisions - all decisions before Lula's administration (1990-2002), and decisions during the Lula administration (2003-10).

We first look for evidence of ideological decision making from the preLula period. Figure 2 compares the distribution of judicial ideal points for the pre-Lula period, before any Workers' Party appointments reached the court, and after. The pre-Lula graph shows no clear or obvious pattern of groupings by appointing president. The Collor, Sarney, and military appointees span the entire space, vertically and horizontally. The handful of Cardoso and Franco appointees are clustered, but so few that they do not suggest any trend. Column 3 of Table 1 tests for significant differences between group means (ranks, for Kruskal-Wallis) for the pre-Lula period. None of the five tests on any dimension 1 or dimension 2 was significant. 
Table 1. Analysis of Variance on Judicial Ideal Points as a Function of Appointing President

\begin{tabular}{|c|c|c|c|c|}
\hline & $\begin{array}{l}\text { All Cases } \\
\text { 1990-2010 }\end{array}$ & $\begin{array}{l}\text { Without Outlier } \\
\text { 1990-2010 }\end{array}$ & $\begin{array}{l}\text { Pre-PT } \\
\text { 1990-2002 }\end{array}$ & $\begin{array}{l}\text { Post-PT } \\
\text { 2003-2010 }\end{array}$ \\
\hline \multicolumn{5}{|l|}{ ANOVA } \\
\hline \multicolumn{5}{|l|}{ Dimension 1} \\
\hline F-statistic & 6.59 & 8.26 & 1.703 & 3.39 \\
\hline$p$-Value & $<0.001^{\star \star \star \star}$ & $<0.001^{* \star * *}$ & 0.195 & $0.034^{\star *}$ \\
\hline \multicolumn{5}{|l|}{ Dimension 2} \\
\hline F-statistic & 1.94 & 3.22 & 0.42 & 1.732 \\
\hline$p$-Value & 0.126 & $0.03^{* \star}$ & 0.817 & 0.109 \\
\hline \multicolumn{5}{|l|}{ MANOVA } \\
\hline F-statistic & 3.68 & 4.98 & 0.96 & 2.71 \\
\hline$p$-Value & $0.001^{\star * \star}$ & $<0.001^{\star \star \star *}$ & 0.607 & $0.021^{\star \star}$ \\
\hline \multicolumn{5}{|l|}{ Kruskal-Wallis } \\
\hline \multicolumn{5}{|l|}{ Dimension 1} \\
\hline K-W chi-squared & 17.10 & 18.42 & 8.38 & 13.152 \\
\hline$p$-Value & $0.009^{* * *}$ & $0.005^{* * *}$ & 0.136 & $0.041^{*}$ \\
\hline \multicolumn{5}{|l|}{ Dimension 2} \\
\hline K-W chi-squared & 11.76 & 13.82 & 2.90 & 9.573 \\
\hline$p$-Value & $0.067^{*}$ & $0.03^{\star \star}$ & 0.716 & 0.144 \\
\hline Excludes Marco Aurelio? & No & Yes & Yes & Yes \\
\hline Number of judges & 25 & 24 & 16 & 13 \\
\hline
\end{tabular}

${ }^{*}=0.10,{ }^{* *}=0.05,{ }^{* \star *}=0.01,{ }^{* \star \star \star}=0.001$.

The table above tests for cohort differences in ideal points for different periods using a variety of methods. In each case, the dependent variable is the judicial ideal point and the independent variable is a set of indicator variables for the appointing president. Each set of results tests whether there are significant differences in ideal points when comparing the judges appointed by different presidents. Results suggest that there are differences in judges but these differences only appeared after President Lula began appointing judges to the court, and results are robust to the removal of an outlier.

Figure 3 examines the distribution of judicial ideal points for STF decisions after 2003, that is, after President Lula of the PT (Workers' Party) began appointing judges. The figure is not as clean as Figure 1, but does show a clear separation between the PT justices and the rest of the court. Again, other presidents' appointees are also grouped, though less decisively than before, which is not surprising given the smaller dataset available when restricting analysis to these eight years. Column 4 of Table 1 tests for significant appointing-president differences. Results here are not as strong as before, but still very consistent. Using the Kruskal-Wallis and ANOVA tests, there are significant differences between judges based on their appointing presidents. The multidimensional MANOVA also finds a significant difference between group means. The second dimension in this case, however, does not reveal significant group differences.

Is the new cleavage just the result of PT versus non-PT conflict, as the first PT appointed judges join the court? Or does it reflect institutional change? We might divide the Lula administration into two time periods: the two years before the judicial reform, and the six years after the judicial 


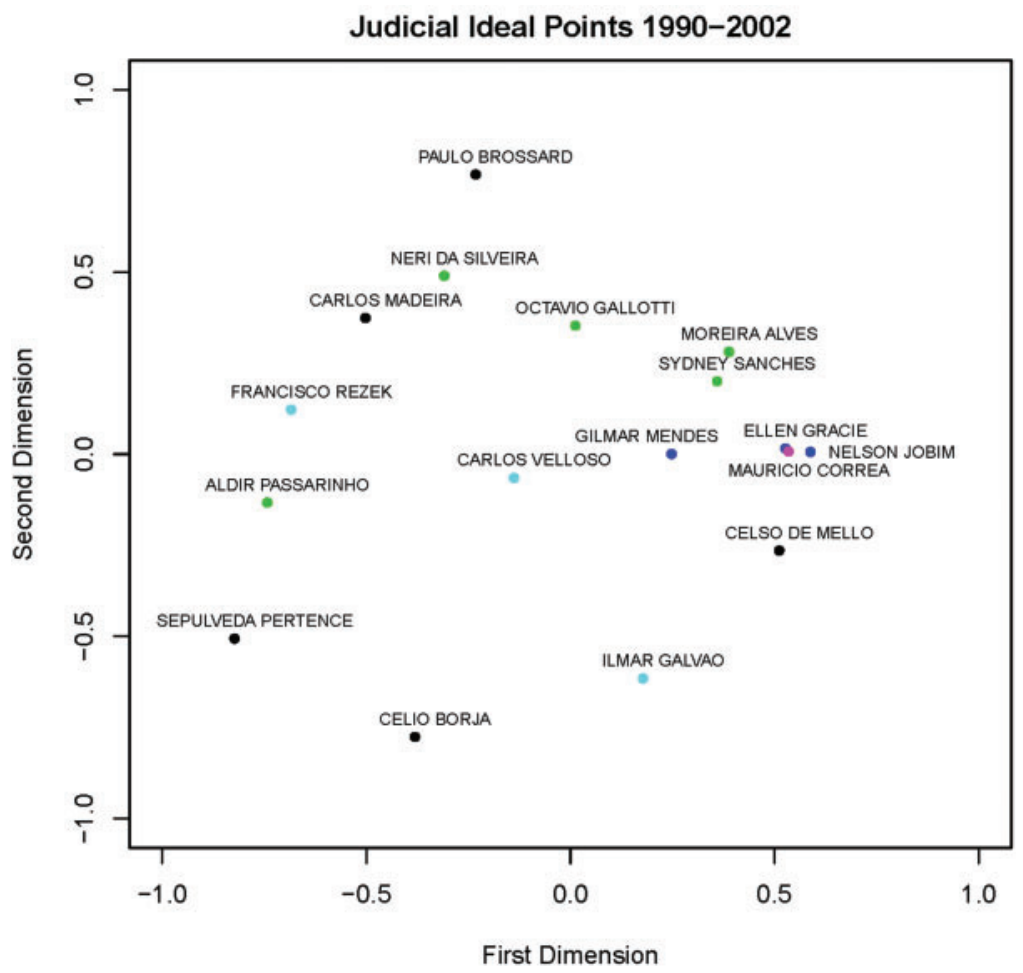

Figure 2. Pre-Lula Ideal Points, 1990-2002.

reform. If the new cleavage is just the result of PT appointments to the court, then we should see the cleavage in both periods. If, however, the increase in constitutional authority activates partisan cleavage and changes judicial behavior, then this separation should only appear after the 2004 reforms took effect. Indeed, when splitting the two periods, the results are only significant after the reforms (not shown) ${ }^{20}$ However, these results rely on few observations and fairly heroic assumptions. For a more robust test, we turn to a nonparametric method.

\section{Permutation Analysis}

To complement our spatial analysis, we also applied a nonparametric permutation approach. This approach resolves three potential problems with the spatial model. First, there is a lifecycle or generational bias in ideal point estimation that occurs naturally when analyzing long

20. In this case, the assumptions of our tests are questionable as the number of judges is very small. As an alternative, below, we apply a nonparametric analysis that confirms these results. 
Judicial Ideal Points, 2003-2010

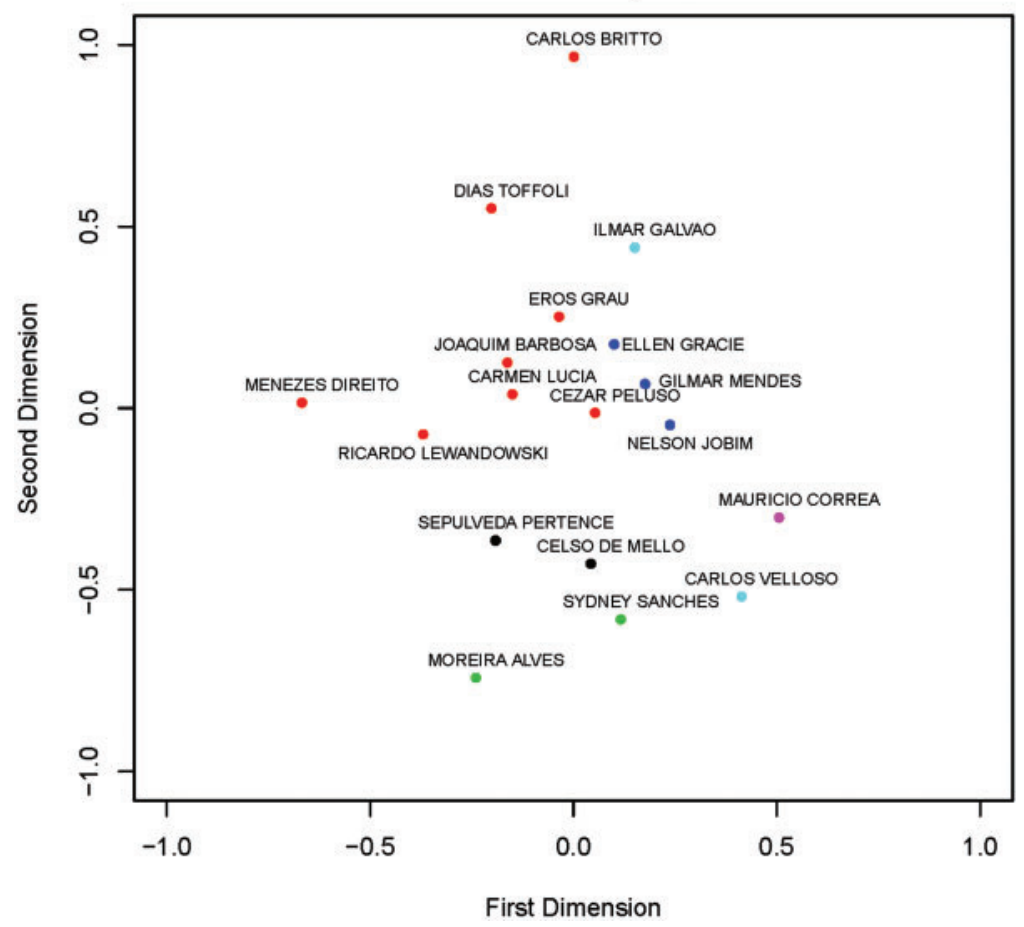

Figure 3. Ideal Points under Lula, 2003-2010.

legislative periods. Often in such cases, judges (and legislators) ideal points are jointly estimated into a single space although they may have never served on the same court. In Brazil, with a mandatory retirement age, there has been substantial turnover on the court. In the 20 years in our study, a total of 29 different justices served on the court, which has 11 seats. ${ }^{21}$ The result is that our analysis jointly estimates ideal points for justices chosen by military presidents in the 1980s as well as justices selected by the first leftist president since the military coup of 1964, President Lula. When estimating ideal points with such generational data, there is a natural bias in ideal point estimation toward separation by generation; the nonparametric method suffers no such bias. ${ }^{22}$

The second advantage of a nonspatial model is that it aggregates all dimensions, instead of just relying on the low dimensional space typically estimated. In our case, the predictive power of the first two dimensions in

21. Over the past 20 years, only 17 justices have served on the nine-seat United States' Supreme Court.

22. We show this in a separate working paper. 
this analysis, while substantial, was lower than in many judicial bodies. The nonparametric permutation technique detects voting blocs without any constraints of dimensionality. The method we use has been discussed elsewhere in the literature (Desposato 2003; 2004) and software for conducting the analysis is available through the $\mathrm{R}$ computing platform. Finally, the ANOVA analysis conducted on a small dataset with fewer than 30 judges risks violating that method's assumptions; permutation analysis has no such limitations with small datasets.

Table 2 shows results from a nonparametric test for presidential cleavages in justice decisions. The permuted range shows the range of mean justice-president cohesion that would be expected just due to chance. The figures are Rice cohesion scores for each justice-president coalitiontreating each president's appointees as a voting bloc, just as legislative studies examine parties (Desposato 2003). The observed score is the mean cohesion for these voting blocs. There is evidence of presidentbased splits in decisions whenever the actual cohesion is higher than the range of permuted values. The last column reports the effective $p$-valuethis is the percentage of permuted scores that are larger than the actual scores (if the $p$-value is 0.05 , that means that only $5 \%$ of permuted values are greater than the actual observed score, suggesting significance at the 0.05 level). Note as well that this permutation analysis automatically adjusts for any small bloc inflation of cohesion scores.

The results parallel the ideal point analysis, and confirm our earlier findings. When lumping the entire period, there is a small but statistically significant effect: justices, on average, appear to be split into blocs for decision making. However, when we just look at the pre-Lula period, there is no evidence of significant splits into decision blocs based on presidential appointments.

Conversely, just looking at the Lula period, there are consistently significant voting bloc effects no matter how we parse the data. Looking at all justices, and treating each set of presidential appointments as a different voting bloc, observed voting bloc cohesion exceeds all 10,000 permuted values - evidence of cleavages significant at the 0.0001 level. We also compared two other approaches. In the first, noting Marco Aurelio's erratic behavior, we dropped him from the analysis. This had no impact on our results. In the second, we lumped all the non-Lula judges together in a single bloc and compared Lula and non-Lula appointees' behavior. In this case, if our results persisted they provide evidence that the key cleavage is between the Lula appointees and earlier justices - as suggested by our spatial analysis. Again, there was evidence of cleavages, significant at the 0.0001 level.

Our critical test again is comparing the decisions from the Lula administration, before and after the reform. A test for ideological cleavages for the first two years of the Lula administration (2003-04) and the last six years (2005-10) is included in the table, and confirms our hypotheses: there is no significant party-based division on the court-even with the 
Table 2. Group Cohesion: Permutation Analysis of Cleavages on STF by Appointing President

\begin{tabular}{lllc}
\hline & Permuted range & Observed & $\begin{array}{c}\text { Effective } \\
\text { significance }\end{array}$ \\
\hline Entire period & $(0.631,0.666)$ & 0.665 & 0.0002 \\
$\begin{array}{l}\text { Pre-Lula: 1990-2002 } \\
\text { Lula: 2003-2010 }\end{array}$ & $(0.634,0.677)$ & 0.652 & 0.615 \\
$\quad$ All justices & $(0.602,0.670)$ & 0.697 & $<0.0001$ \\
$\quad$ Without Marco Aurelio & $(0.561,0.643)$ & 0.648 & $<0.0001$ \\
$\quad$ Lula / Anti-Lula blocs only & $(0.564,0.646)$ & 0.648 & $<0.0001$ \\
Lula: before and after reforms & & & 0.159 \\
$\quad \begin{array}{l}\text { Pre-reform (2003-04) } \\
\text { Post-reform (2005-2010) }\end{array}$ & $(0.603,0.746)$ & 0.691 & $<0.0001$ \\
\hline
\end{tabular}

The permuted and observed values are average Rice cohesion scores, calculated across all cohors and decisions. Voting cohorts are defined by appointing president. Permuted scores show the full range of cohesion scores observed when randomly assigning votes to groups. Observed scores show actual mean cohesion. When observed cohesion is significantly higher than randomly permuted cohesion, this is evidence that judges are voting together in groups defined by appointing president. In the table above, figures show significant voting decisions emerged after Lula's appointment of PT judges to the court and after significant reforms took effect in 2005.

presence of PT-appointed judges - until the judicial reform takes effect. An effective $p$-value from the permutation analysis is 0.16 . After the reform, there is a stark difference-the permutation analysis reveals a consistent party cleavage on judicial decisions, significant beyond the 0.0001 level.

There are several other notable features of the data that deserve attention. Note first that all the cohesion scores are relatively low when compared with party cohesion in legislatures. For instance, in Brazil, party cohesion scores generally range from 0.70 to 0.85 , and can be as high as 0.97 (Figueiredo and Limongi 1995). The implication is that, while cleavages exist, they are substantially less rigid and consistent than those observed in legislative parties.

Combined, the ideal point estimates and the permutation analysis support Hypothesis 2. The cleavage on the Brazilian high court does not appear until after the 2004 reform increased judicial policy-making authority. There is no evidence that it emerged after a weaker reform in 1999, no evidence that it emerged with President Cardoso's appointments, and no evidence that it emerged with President Lula's pre-reform appointments to the court.

\section{From Majority Splits to Qualitative Analysis}

These quantitative results are consistent, robust to multiple methods, and suggest a fundamental transformation in the court. For additional evidence, we examined a case in which all Lula judges voted as a block to analyze the arguments employed by judges within those cases and to try 
to identify the nature of the separation of Lula's judges from others. Leveraging the majority splits analysis to identify exemplars, ADI 1194 emerges as an illustrative case. ${ }^{23}$ This decision on the merits considered whether it was constitutional for a law to require that any documents establishing legal personality (e.g., to register a small business or organization) would be legally void if not reviewed and approved by an attorney. This was important because it pitted the liberty interest of individuals to form commercial or civic organizations against the institutional interest of the legal profession to maintain a source of business activity and income, as well as the public interest in ensuring that business and civic organizations were operating properly. The majority found this provision constitutional, agreeing with the national bar association (OAB) that there were potential harms from improper contracts that could be avoided if all individuals seeking legal personhood were required to consult an attorney. Thus, the majority voted to support the lawyers' association that an attorney's services were always required in order to form a business or civic organization. This majority consisted of Mauricio Correa, Nelson Jobim, Sepulveda Pertence, Carlos Velloso, Celso de Mello, and Ellen Gracie. None of the Lula justices were in the majority. The minority, on the other hand, was composed of five justices, three of which were Lula appointees: Carlos Britto (Lula), Cezar Peluso (Lula), Joaquim Barbosa (Lula), Gilmar Mendes (Cardoso), and Marco Aurelio (Collor).

The Lulista-heavy minority argued the provision was unconstitutional, finding that it was corporatist in generating more income for lawyers (e.g., Peluso at 75), and emphasizing that such a law violated core principles of legal interpretation, as well as basic individual rights and liberties of association. Two things differentiate the minority position: an appeal to principles, even from international or comparative law, and an appeal to substantive due process. While Mendes writes the lead dissent, elaborating on principles of necessity and proportionality, as well as bureaucratic efficiency (e.g., Mendes at 36, 86), his arguments are rather stiff and procedural compared with those of Lula judges. The Lula judges join Mendes in finding the provision unconstitutional; however, all of the Lula judges - Barbosa, Britto, and Peluso - go well beyond Mendes to emphasize basic principles related to individual liberties, rights, and guarantees. The tenor of these arguments evokes the rights-protectiveness of neoconstitutional profiles seen elsewhere in the region. Barbosa opposes the law because it infringes fundamental liberties of association, commerce, and contract (72). Britto opposes the law because it offends individual rights and liberties (73). And Peluso opposes the law based in part on the principle of substantive due process (75-76). Overall, all three Lula justices appeal to principles - emphasizing individual rights and liberties-, whereas the justices in the majority make rather formal, textual

23. Full-text versions of decisions cited in this section are available at the STF web site, stf.jus.br. 
readings of the constitutional provisions (e.g., Correa's majority opinion, at 26). Indeed, Jobim criticizes Mendes, who was with Lula's justices in the minority, and his appeal to underlying principles, accusing him of German essentialism and stating this essentialism cuts against the preferred guidance of positivists like Brazilian Julio de Castilhos (84). The principlesversus-positivism divide between Lula and non-Lula justices, respectively (with the exception of Mendes), suggests that the dissension of Lula justices is motivated in part by a more progressive view of constitutional interpretation, which would also overlap or coincide with a more leftleaning ideological perspective.

The reference to substantive due process is remarkable in a civil law country and further evidence of the nature of this split. Procedural due process stands for the proposition that there are certain constitutionally recognized rights and that the government cannot infringe on these rights without going through an appropriate set of procedures. This is what is commonly understood as due process. However, substantive due process goes one step further and says that there are some substantive rights, though perhaps not enumerated in the constitution, that cannot be infringed upon. This doctrine is controversial even in the United States, and has been used to find conservative economic rights in the late 19th century and early 20th century, and later to find progressive social rights in the late 20th century. In either case, the right is not enumerated but can be inferred from the overall structure of procedural protections. For instance, the right to "privacy" in progressive reproductive rights jurisprudence in the United States is not enumerated, but was inferred from other due process provisions. Thus, the fact a Lula-appointed justice is appealing to a rights-expansive principle, and one that is controversial in other parts of the world, is further evidence that the division between Lula and non-Lula judges is ideological.

\section{Discussion}

A growing literature on the Brazilian judiciary suggests that this institution is immune from the politicization observed in other courts, especially the United States. According to this research, judges make decisions based on their understandings of legal issues or on other pragmatic considerations, and ideology plays little role in outcomes or behavior. Most of this work is based on case studies by scholars and legal observers, but the core conclusions are also supported by econometric analyses (e.g., Taylor 2008; Oliveira 2008; Jaloretto and Mueller 2011). Our results cut against all of these previous findings.

In this paper, we have examined all available ADI decisions through June 2010. Analysis of all decisions in this important class of constitutional cases during this period found a clear ideological dimension to the ideal space of the Brazilian Supreme Court, driven almost entirely by the appointees of President Lula (2003-10). Decisions prior to his tenure 
showed no impact of appointing president on ideal point or outcomes. But adding the Lula justices to the court fundamentally changed the judicial space, with a clear division between judges appointed by Lula and other appointees. Furthermore, these cleavages appear after the implementation of a major judicial reform that greatly enhanced the policy-making authority of judges. These results suggest an important transition in this civil law judiciary - from a legalist, formalist approach to decision making to a broader, activist, attitudinal model.

The challenge for us - and other scholars of judicial politics - is to understand why and how this change has occurred, and what these patterns imply about comparative judicial behavior. We believe-but cannot establish definitively - that the two changes we discussed earlier played an important role in this evolution. First, the judicial reform that dramatically increased the impact of every STF decision and therefore augmented judicial authority, and second, the rise of the disciplined and ideological PT and its capturing of the presidency in 2002 (and again in 2006, and 2010!).

We believe that the judicial reform affected the STF both directly and indirectly. Directly, the increased influence of the court has brought more focus on programmatic motivations for judicial decisions, and more pressure. Before the 2004 reforms, decisions at the STF applied only to the case at hand and had no broader impact. The interested parties were usually relatively few in number, the scope and impact limited, and the press, politicians, and citizens had little reason to monitor the court. The rise of the súmula vinculante, even if few in number, means that STF decisions have the potential for far greater implications for lower courts and other public authorities. Coupled with the rise of an objective framing or way of thinking about all constitutional litigation, the stakes of each decision have increased manifold. The court is a far more significant and centralizing political actor since 2004. For judges, this implies strong incentives to apply broad principled arguments to their decisions - drawing on their judicial ideology-rather than narrow, case-specific considerations. Given the diversity of judges on the court, the result was a new cleavage.

Indirectly, the reforms could change appointment strategy, especially over the longer term. With new sweeping powers vested in the STF, strategic presidents should be more careful to appoint like-minded and friendly justices who will side with the appointing president and carry forward his or her policy legacy. In other words, presidents may have new incentives to appoint increasingly political justices. This is exactly the change observed: recent judicial appointees have held prior political positions - Dias Toffoli is the starkest example - and only three of Lula's seven appointments held prior judgeships. This pattern cuts against the conventional civil law standard of recruiting professional judges into these positions, though again it is a matter of degree; Lula's predecessors also did some of this, but Lula did more of it and deliberately sought to place 
sympathetic, leftist judges on the court, as evidenced by his reactions above when a decision was against him.

Of course, we cannot separate out the broader impact of the reforms on appointment strategy and the changes wrought by the PT's own nature. As the most successful of Brazil's parties, with high levels of organization and discipline, it is not surprising that PT judicial appointments are themselves increasingly political, progressive, and aligned with the party. To be clear, it is less likely that this is a division along a simple, left-right continuum, and more likely that it is a division according to schools of legal interpretation, with the non-Lula judges standing for more positivist views conventionally associated with civil law judges and Lula judges representing a more principled view associated with interpretivism or progressive constitutionalism (see Couso 2010; Couso and Hilbink 2011; Rodriguez Garavito 2011).

Future research will help resolve these issues; one promising avenue of research - though labor intensive - would be to collect more data on remaining STF decisions. Our web-scraping found many other types of decisions which could be used to examine judicial behavior more closely, but as discussed above, coding these requires reading each case and entering each decision by hand. We invite other scholars to join this research agenda using the data from this project, released on our website.

For Brazil, the transition could be positive - or negative. On the positive side, increased attention and principled position taking may be an important step toward modernizing Brazil's legal system, improving the business environment through a more efficient and principled legal culture and judicial decision process, and enhancing rights protections. More broadly, the transition may reflect the maturation of the political environment, reflecting the evolution of the political system seen elsewhere, for example, in legislative politics.

On the other hand, this transition could signal a new politicization of the judiciary that destroys judicial autonomy and merely extends presidential power. Since Brazilian justices must retire by age 70 , there is more turnover on that court than on many others, and most presidents can appoint several justices to the court. Indeed, as of November 2011, the Workers' Party has won three consecutive presidential elections and seen enough retirements (and one death) to be able to appoint eight of eleven sitting justices - enough to overrule any minority opposed to deliberation, and clearly an unprecedented supermajority. If President Dilma Rousseff wins re-election in 2014, she will nominate replacements for two additional justices that will be termed out by their age-guaranteeing 10 of 11 Supreme Court seats for the Workers' Party. If the court is increasingly politicized, this is a staggering concentration of power, and cause for concern.

More broadly, for comparative judicial studies, our study of the Brazilian Supreme Court provides an interesting illustration of transition in the nature of judicial politics. The transition appears to be driven by 
institutional change combined with political change, while the broader legal environment was held constant. Our results contribute to a growing literature on judicial behavior in civil law settings, and especially to those documenting changes in legal culture and a widening division between more traditional, passive, positivist judges, and more progressive, active, assertive, interpretivist judges like that documented in Spain, Chile, and elsewhere (Hilbink 2007a; 2007b; 2012; Couso 2010; Huneeus 2010; Ingram 2012). Thus, our findings challenge the existing literature on the persistent, apolitical professionalism of the Brazilian STF, highlighting a crucial new cleavage in Brazilian judicial politics, but also complement recent studies that examine transformations in judicial behavior in the civil law tradition.

\section{Appendix A}

\section{Clarification Regarding Justice Marco Aurelio}

The exclusion of Marco Aurelio's dissents requires some clarification. Our qualitative analysis of his judicial style, as well as a review of secondary work suggests that his behavior is either nonspatial and erratic, or perhaps on some higher dimensional space not shared by the other justices. Many nonunanimous cases on the STF have just a single dissenter, Marco Aurelio, and all evidence is that his behavior is as much driven by a desire to be contrarian as by a well-defined set of legal principles.

Furthermore, we note that in our nonparametric analysis, the inclusion or exclusion of Justice Aurelio does not affect our results; our findings of emerging cleavages are robust to his presence or absence. But on the lowdimensional spatial analysis, his behavior - often alone in the minoritydominates the judicial space, and warrants some consideration.

A 20-year retrospective of his career on the STF highlighted his reputation as a consistently lone dissenter and noted his "absolute independence" and "trademark of divergence" (sina de divergir; Haidar 2010). His frequent solo dissents - paired with his fondness for being in the media - caused many observers of the STF to think his dissents are due more to whim and capriciousness than to principled conviction (Haidar 2010). ${ }^{24}$ Marco Aurelio himself stated in an interview that he "never made a point of being part of any majority," much less unanimity (quoted in Haidar). Elsewhere, he has been quoted as saying that he and his colleagues are not on the court to agree with each other, emphasizing that they are not "vaquinhas de presépio" (Pardelas 2008), a colloquialism that

24. Haidar notes that some of Marco Aurelio's dissenting positions have later been adopted as the Court's majority position on an issue. However, it is not clear that this is a systematic phenomenon or simply an artifact of the fact Marco Aurelio has dissented on so many issues that one of his dissents is bound to be adopted by a later court. 
roughly means “obsequious flunky."25 Marco Aurelio’s quixotic behavior has earned him many adjectives and nicknames, including the neutral "countermajoritarian" (contramajoritario), a play on the nonmajoritarian constitutional role of the STF. Justice Nelson Jobim equated the persistently divergent opinions of Marco Aurelio to "an awful little dentist's drill" (chato motorzinho de dentista; Haidar). Another nickname among his colleagues is perhaps most revealing - ministro voto vencido, or "justice of the defeated vote" - capturing the predictability with which he dissents from the majority decisions (Gonçalves Couto 2009; see also Kapiszewski 2010: 72, n.46).

To be sure, Marco Aurelio's dissents may be a product of personality and preferences as well as the Brazilian legal system. Taylor (2008: 34) notes that in civil law systems like Brazil, judges are generally understood to apply the law in rather straightforward, apolitical manner. However, Brazil has so many laws that it is not unusual to find laws cutting in opposite directions, a phenomenon that allows STF judges wide latitude in choosing which law to apply. Taylor quotes Marco Aurelio describing his decision-making strategy: "First I imagine the most just solution... only afterward do I seek support in the law" (Erdelyi 2006; Taylor 2008: 34, citing Amorim Alves 2006: 22). Marco Aurelio's dissents, then, would seem to hinge on what he personally deems "just" and he is unlikely to be swayed by purely legalistic arguments, leaving ample room for disagreement. In sum, Marco Aurelio's solo disagreements with his colleagues are a regular occurrence, so much so that his style of decision making has taken on an idiosyncratic quality, justifying excluding him from the analysis.

Having said this, it is important to note that acknowledging his pattern of dissents does not necessarily mean that Aurelio's decisions lack any political motivation. Kapiszewski highlights injunctions issued by Marco Aurelio on two crucial cases that suspended political deliberations: (1) the plebiscite regarding a new form of government (ADI 829, ADI 830), and (2) congressional deliberations regarding social security reform (MS 22503). In both of these cases, "crucial political processes ground to a halt as a result of these suspensions" (Kapiszewski 2010: 70-71). Thus, while we have methodological reasons to remove Marco Aurelio from the analysis, we remain cognizant that his behavior on the court may not be apolitical.

\section{References}

Amaral-Garcia, Sofia, Nuno Garoupa, and Veronica Grembi. 2009. "Judicial Independence and Party Politics in the Kelsenian Constitutional Courts: The Case of Portugal," 6 Journal of Empirical Legal Studies 381-404.

25. Fuller quote: "O colegiado é um somatório de forças distintas. Não estamos ali para concordar um com o outro. Não somos vaquinhas de presépio. Cada qual deve revelar o seu convencimento." 
Amorim Alves, Paulo Cesar. 2006. O tempo como ferramenta de decisão no STF: Um mapeamento da seletividade do tribunal nos tempos processuais das ações diretas de inconstitucionalidade. Thesis, Escola de Formação da Sociedade Brasileira de Direito Público.

Baum, Lawrence. 2006. Judges and their Audiences: A Perspective on Judicial Behavior. Princeton: Princeton University Press.

Bhatia, Kedar. 2013. Updated October Term 2013 Stat Pack and key takeaways SCOTUSblog (Apr. 11, 2014, 10:30 AM). Available at: http://www.scotusblog.com/ 2014/04/updated-october-term-2013-stat-pack/ (last accessed May 1, 2014).

Brinks, Daniel. 2005. "Judicial Reform and Independence in Brazil and Argentina: The Beginning of a New Millennium?," 40 Texas International Law Journal 595-622.

_. 2011. "Faithful Servants of the Regime': The Brazilian Constitutional Courts Role under the 1988 Constitution," in G. Helmke, and J. Ríos-Figueroa, eds, Courts in Latin America. New York: Cambridge University Press.

Camargo, Marcelo Novelino. 2006. "O efeito vinculante nas decisões do Supremo Tribunal Federal,"Jus Navigandi Teresina, ano 11, n. 1136, (August 11). Available at: http://jus. com.br/revista/texto/8769 (last accessed May 14, 2013).

Constitutional Amendment 45 (EC 45/2004). Full Portuguese text available at: http://www. planalto.gov.br/ccivil_03/constituicao/emendas/emc/emc45.htm (last accessed March 30, 2012).

Couso, Javier. 2010. "The Transformation of Constitutional Discourse and the Judicialization of Politics in Latin America," in J. Couso, A. Huneeus, and R. Sieder, eds, Cultures of Legality: Judicialization and Political Activism in Latin America. New York: Cambridge University Press.

Couso, Javier, and Lisa Hilbink. 2011. "From Quietism to Incipient Activism: The Institutional and Ideational Roots of Rights Adjudication in Chile," in G. Helmke, and J. Ríos-Figueroa, eds, Courts in Latin America. New York: Cambridge University Press.

Desposato, Scott W. 2003. "Comparing Group and Subgroup Cohesion Scores: A Nonparametric Method with an Application to Brazil," 11 Political Analysis 275-88.

2. 2004. "The Impact of Federalism on National Party Cohesion in Brazil," 29 Legislative Studies Quarterly 259-85.

Epstein, Lee, and Jack Knight. 1998. The Choices Justices Make. Washington, DC: CQ Press.

Erdelyi, Maria Fernanda. 2006. "Lula sanciona leis para racionalizar o Judiciário,"Consultor Jurídico (Dec. 19).

Figueiredo, Argelina, and Fernando Limongi. 1995. "Partidos Políticos na Câmara dos Deputados: 1989-1994," 38 Dados 497-524.

Garoupa, Nuno, Fernando Gomez-Pomar, and Veronica Grembi. 2013. "Judging under Political Pressure: An Empirical Analysis of Constitutional Review Voting in the Spanish Constitutional Court," 29 Journal of Law, Economics, and Organization 513-34.

Ginsburg, Tom. 2003. Judicial Review in New Democracies. Cambridge: Cambridge University Press.

Gonçalves Couto, Claudio. 2009. "A pior indicação de Lula," Valor Econômico (Sep. 21).

Haidar, Rodrigo. 2010. "Marco 2.0: Marco Aurelio completa 20 anos de Supremo," Consultor Juridico (June 14). At: http://www.conjur.com.br/2010-jun-14/marco-aureliocompleta-20-anos-supremo-tribunal-federal.

Helmke, Gretchen. 2005. Courts under Constraints: Judges, Generals, and Presidents in Argentina. New York: Cambridge University Press.

Hilbink, Lisa. 2007a. Judges Beyond Politics in Democracy and Dictatorship: Lessons from Chile. Cambridge: Cambridge University Press.

—. 2007b. "Politicising Law to Liberalise Politics: Anti-Francoist Judges and Prosecutors in Spain's Democratic Transition," in T. C. Halliday, L. Karpik, and M. M. Feeley, eds, Fighting for Political Freedom: Comparative Studies of the Legal Complex and Political Liberalism. Portland, OR: Hart Publishing. 
2012. "The Origins of Positive Judicial Independence," 64 World Politics (October).

Hirschl, Ran. 2004. Towards Juristocracy: The Origins and Consequences of the New Constitutionalism. Cambridge: Harvard University Press.

Hunneus, Alexandra. 2010. "Rejecting the Inter-American Court: Judicialization, National Courts, and Regional Human Rights," in J. Couso, A. Huneeus, and R. Sieder, eds, Cultures of Legality: Judicialization and Political Activism in Latin America. New York: Cambridge University Press.

Ingram, Matthew C. 2012. "Crafting Courts in New Democracies: Ideology and Judicial Council Reforms in Three Mexican States," 44 Comparative Politics 439-58.

ISTOÉ. 2000. "Ex-clube do Bolinha," Nov. 3, 2000 (Brazil); available at: http://www.istoe. com.br/reportagens/43500_EX+CLUBE+DO+BOLINHA (last viewed May 31, 2012).

Jaloretto, Maria F., and Bernardo P. M. Mueller. 2011. "O Procedimento de Escolha dos Ministros do Supremo Tribunal Federal - uma análise empírica," 2 Economic Analysis of Law Review 170-87. Available at: ealr.com.br (last accessed July 20, 2011).

Kapiszewski, Diana. 2010. "How Courts Work: Culture, Institutions, and the Brazilian Supremo Tribunal Federal," in Javier Couso, Alexandra Huneeus, and Rachel Sieder, eds, Cultures of Legality: Judicialization and Political Activism in Contemporary Latin America. Cambridge: Cambridge University Press.

_. 2011a. "Power Broker, Policymaker, or Rights Adjudicator? The Brazilian Supremo Tribunal Federal in Transition,” in Gretchen Helmke, and Julio Ríos-Figueroa, eds, Courts in Latin America. Cambridge: Cambridge University Press.

- 2011b. "Tactical Balancing: High Court Decision-Making on Politically Crucial Cases," 45 Law and Society Review 471-506.

- 2012. High Courts and Economic Governance in Argentina and Brazil. Cambridge: Cambridge University Press.

Law 9.868/99 (Lei 9.868/99). Dispõe sobre o processo e julgamento da ação direta de inconstitucionalidade e da ação declaratória de constitucionalidade perante o Supremo Tribunal Federal. Nov. 10, 1999. Available at: http://www.planalto.gov.br/ccivil_03/ leis/19868.htm (last accessed May 15, 2013).

Law 11.417/06 (Lei 11.417/06). Regulamenta o art. 103-A da Constituição Federal e altera a Lei no 9.784, de 29 de janeiro de 1999, disciplinando a edição, a revisão e o cancelamento de enunciado de súmula vinculante pelo Supremo Tribunal Federal, e dá outras providências. Dec. 19, 2006. Available at: http://www.planalto.gov.br/ccivil_03/_ato20042006/2006/lei/111417.htm (last accessed May 15, 2013).

Law 11.418/06 (Lei 11.418/06). Acrescenta à Lei no 5.869, de 11 de janeiro de 1973 - Código de Processo Civil, dispositivos que regulamentam o § 3o do art. 102 da Constituição Federal. Dec. 19, 2006. Available at: http://www.planalto.gov.br/ccivil_03/_ato20042006/2006/lei/111418.htm (last accessed May 15, 2013).

Leoni, Eduardo L., and Antonio P. Ramos. 2006. "Judicial Preferences and Judicial Independence in New Democracies: The Case of the Brazilian Supreme Court," (unpublished manuscript dated August 25, 2006).

Martin, Andrew D., and Kevin M. Quinn. 2002. "Dynamic Ideal Point Estimation via Markov Chain Monte Carlo for the U.S. Supreme Court, 1953-1999" 10 Political Analysis 134-53.

Nunes, Rodrigo. 2010. "Ideational Origins of Progressive Judicial Activism'," 52 Latin American Politics and Society 67-97.

Oliveira, Fabiana Luci. 2008. "Justice, Professionalism, and Politics in the Exercise of Judicial Review by Brazil's Supreme Court," 2 Brazilian Political Science Review 93-116.

Pardelas, Sergio. 2008. "Entrevista: Marco Aurelio Mello,"ISTOÉ (Dec. 31); available at http://www.istoe.com.br/assuntos/entrevista/detalhe/362_A+MULTIDAO+QUER+SA NGUE+E+CIRCO) (accessed 18 October 2014).

Poole, Keith. 2000. "Non-Parametric Unfolding of Binary Choice Data," 8 Political Analysis 211-37.

Powell, Emilia Justyna. 2013. "Islamic Law States and the International Court of Justice," 50 Journal of Peace Research 203-17. 
Powell, Emilia Justyna, and Jeffrey K. Staton. 2009. "Domestic Institutions and Human Rights Treaty Violations," 53 International Studies Quarterly 149-74.

Rodríguez-Garavito, César. 2011. "Toward a Sociology of the Global Rule of Law Field: Neoliberalism, Neoconstitutionalism, and the Contest over Judicial Reform in Latin America," in Yves Dezalay, and Bryant Garth, eds., Lawyers and the Transnationalization of the Rule of Law London: Routledge.

Segal, Jeffrey, and Harold Spaeth. 2002. The Supreme Court and the Attitudinal Account Revisited. Cambridge: Cambridge University Press.

Songer, Donald R., and Julia Siripurapu. 2009. "The Unanimous Decisions of the Supreme Court of Canada as a Test of the Attitudinal Model," 42 Canadian Journal of Political Science 65-92.

Staton, Jeffrey K 2010. Judicial Power and Strategic Communication in Mexico. Cambridge: Cambridge University Press.

Studart, Hugo. 2007. "A escolha de Direito,"ISTOÉ (Sept. 5).

Sunstein, Cass R., David Schkade, and Lisa Michelle Ellman. 2004. "Ideological Voting on Federal Courts of Appeals: A Preliminary Investigation," 90 Virginia Law Review 301-54.

Sunstein, Cass R., David Schkade, Lisa M. Ellman, and Andres Sawicki. 2006. Are Judges Ideological? An Empirical Analysis of the Federal Judiciary. Washington, DC: Brookings Institution Press.

Tate, Neal, and Torbjorn Vallinder. 1995. The Global Expansion of Judicial Power. New York: New York University Press.

Taylor, Matthew M. 2008. Judging Policy: Courts and Policy Reform in Democratic Brazil. Palo Alto: Stanford University Press.

Vanberg, Georg. 2005. The Politics of Constitutional Review in Germany. Cambridge: Cambridge University Press. 